\title{
Synergism between sulphonamide drugs and antibiotics of the polymyxin group against Proteus sp. in vitro
}

\author{
F. E. RUSSELL \\ From the Bacteriology Department, University and Western Infirmary, Glasgow, \\ and the Infectious Diseases Hospital, Paisley
}

SYNOPSIS Interesting synergism in vitro between a recently introduced antibiotic, colistin methane sulphonate, and sulphonamide drugs is described. The observations were extended to polymyxin B sulphate and sulphonamides with essentially similar results. The combinations are bactericidal at $N$ therapeutic levels, the ratio of drugs to one another is not critical, and the effect is present over a 9 fairly wide $p \mathrm{H}$ range.

Since the introduction of colistin methane sulphonate (Colomycin) it has been reiterated that it is inactive at therapeutic levels against Proteus sp. (Carroll and Malette, 1961; Taylor and Allison, 1962).

Synergism in vitro between colistin and sulphafurazole was easily observed on plate sensitivity tests in this laboratory against 23 out of 25 consecutively isolated strains of Proteus (Figs. 1 and 2). The first eight strains isolated conformed in biochemical characteristics to the species Proteus mirabilis, one being a non-spreading variant. Subsequent isolates were assigned to the genus purely on their odour and ability to spread on blood agar.

The synergistic effect was first noticed between a $100 \mu \mathrm{g}$. sulphafurazole disc (Oxoid) and a $300 \mu \mathrm{g}$. Colomycin disc (Mast). The synergism was generally as obvious on ordinary blood agar as on sensitivity test agar (Oxoid). Ordinary wire-loop inoculation of plates was used throughout. The discs were placed $\frac{3}{8}$ in. apart and zones of inhibition varied as in Figure 3.

Although the method of inoculation was crude, in view of the nature of the zones and concentration of the drugs used it was obvious that colistin was potentiating the effect of sulphafurazole.

On preliminary testing four of the isolated strains were apparently sensitive to sulphafurazole, chloramphenicol, and streptomycin, 12 to chloramphenicol and streptomycin, five to streptomycin only, and four to chloramphenicol only. (Kanamycin and ampicillin were not being used routinely at this time.)

Received for publication November 1962
Five strains showing well-marked zones of in- $\vec{\varphi}$ hibition were selected and used to test sulphafurazole $\stackrel{\mathscr{\omega}}{\mathscr{C}}$ in combination with each of the following antibiotics on blood agar plates: penicillin, streptomycin, tetracycline, chloramphenicol, and erythromycin. No synergism was noted. Colistin was tested in combination with the same antibiotics. Again no synergism was noted.

The exact relationship of colistin to members of the polymyxin group, to polymyxin $\mathrm{E}$ in particular, is not yet settled (Cuthbert, 1962; Stewart, 1962) but there appears to be a close similarity. Twentytwo of the original isolates, together with a further $\frac{8}{8}$ three isolates which showed the synergistic effect, $\dot{0}$ making 24 showing syngerism between colistin and sulphafurazole and one which did not, were tested $\delta$ on blood agar for synergism between sulphafurazole 3 $(200 \mu \mathrm{g}$. (Mast)) and filter paper discs impregnated 0 with approximately $200 \mu \mathrm{g}$. polymyxin B sulphate. $D$ The same 24 isolates showed synergism between polymyxin $\mathbf{B}$ and sulphafurazole, the other isolate again being resistant to the combination. Zones of inhibition were smaller than when using colistin $\tilde{S}^{-}$ methane sulphonate and sulphafurazole.

\section{EXPERIMENTAL}

Three isolates, two showing the synergistic effect on plates and one not showing susceptibility, were subjected to the following tube dilution tests. Colistin methane ${ }_{0}^{-}$ sulphonate $(80 \mathrm{mg}$.), polymyxin $B$ sulphate $(83.3 \mathrm{mg}$.), $\overrightarrow{\mathbb{D}}$ and sulphafurazole $\left(0.5 \mathrm{~g}\right.$.) were dissolved or suspended $\frac{\rho}{\mathbb{D}}$ in known volumes of physiological saline. Glucosee peptone water without serum was made up containing (a) $400 \mu \mathrm{g}$. colistin methane sulphonate per $\mathrm{ml}$; (b) 


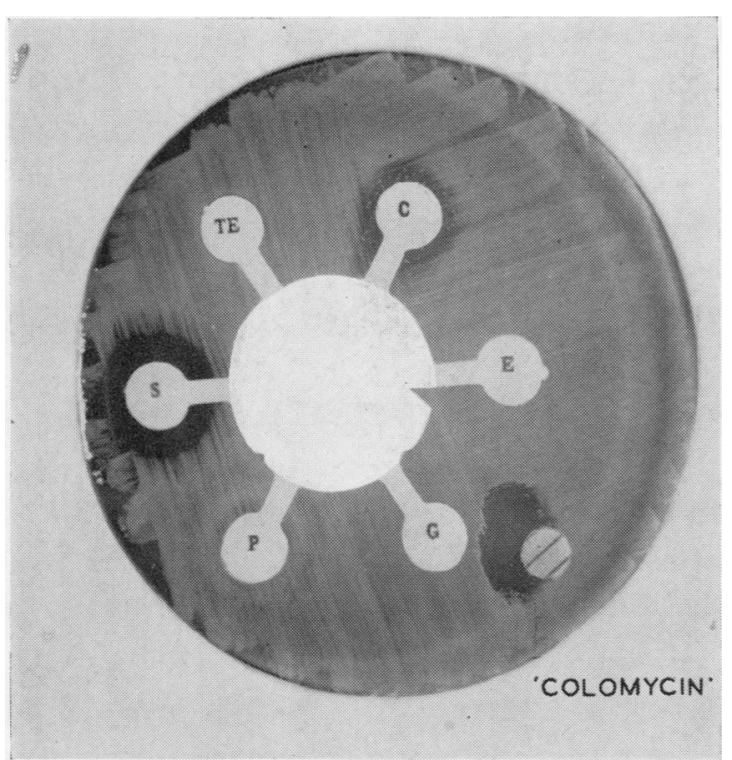

FIG. 1. Synergism between Colomycin and sulphafurazole against a strain of Proteus.

(a)

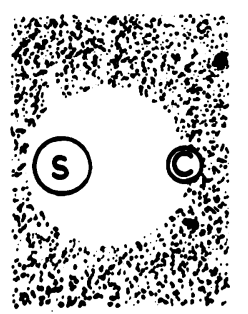

(b)

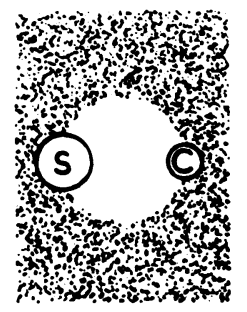

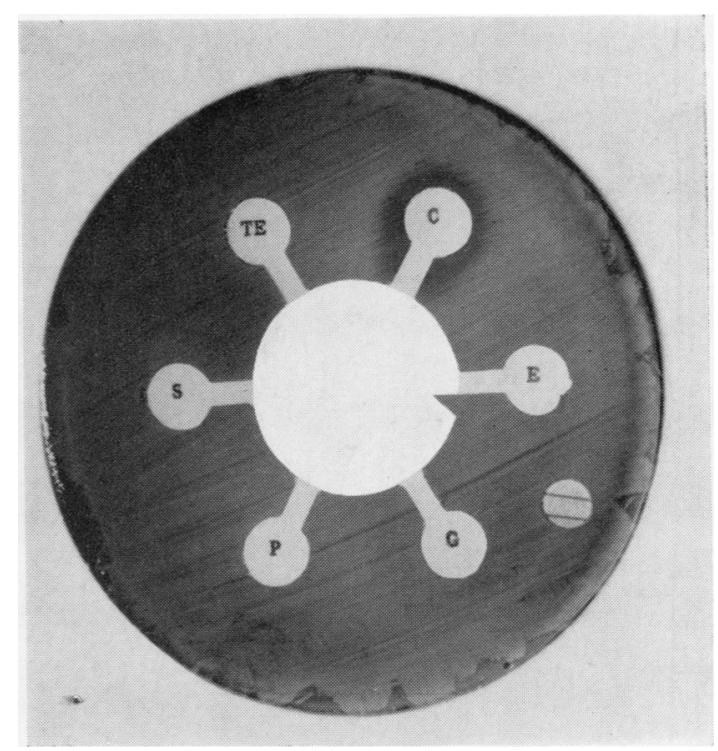

FIG. 2. A different strain of Proteus resistant to the combination of drugs.

(c)

(d)

(e)

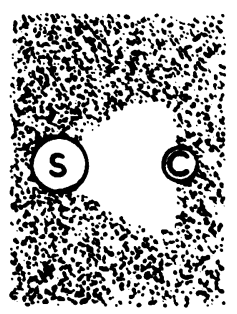

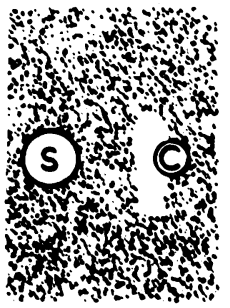

FIG. 3. Varying zones of inhibition of Proteus sp. observed. $\mathrm{C}=$ Colomycin disc $(300 \mu g.) ; \mathrm{S}=$ sulphafurazole disc (100 $\mu \mathrm{g}$.$) .$

$100 \mu$ g. sulphafurazole per ml.; and (c) $400 \mu \mathrm{g}$. colistin methane sulphonate $+100 \mu \mathrm{g}$. sulphafurazole per $\mathrm{ml}$. Eight doubling dilutions were made and the dilutions distributed in $1 \mathrm{ml}$. amounts in Bijou bottles. This procedure was subsequently repeated using $400 \mu \mathrm{g}$. of polymyxin B sulphate per $\mathrm{ml} ., 100 \mu \mathrm{g}$. sulphafurazole per $\mathrm{ml}$., and $400 \mu \mathrm{g}$. polymyxin B sulphate per $\mathrm{ml}$. + $100 \mu \mathrm{g}$. sulphafurazole per $\mathrm{ml}$. as initial concentrations. In every test two drops of an overnight broth culture were added to about $3 \mathrm{ml}$. broth, and one drop of this dilution was used to inoculate each bottle. This, a fairly heavy inoculum, gave semiconfluent growth on MacConkey agar; viable counts were not performed. Bacteriostasis was assessed by acid production after overnight incubation, and bactericidal action after appropriate subculture onto MacConkey agar.

\section{RESULTS}

The results are shown in Tables I to III. These results show that a bactericidal action was achieved with 25 to $50 \mu \mathrm{g}$. colistin methane sulphonate combined with 6.25 to $12.5 \mu \mathrm{g}$. sulphafurazole and with 50 to $100 \mu \mathrm{g}$. polymyxin B sulphate combined with 12.5 to $25 \mu \mathrm{g}$. sulphafurazole.

Two further experiments, using nutrient broth without serum as diluent, were carried out in order to determine how critical the ratio of drugs to one another was, and to see if the $p \mathrm{H}$ of the medium (covering roughly a range which might be found in the lower urinary tract) greatly altered the results. In the first experiment, the technique of inoculation was as before and two different isolates were used, one with colistin and sulphafurazole, the other with polymyxin B and sulphafurazole. The results are in Table IV.

Although the ratio of drugs to one another is not critical, increasing the concentration of sulpha- 
TABLE I

BACTERIOSTATIC EFFECT IN SENSITIVE STRAINS

\begin{tabular}{|c|c|c|c|c|c|c|c|c|c|c|}
\hline Strain & Drugs & Dilu & ition & & & & & & & \\
\hline 1 & $\begin{array}{l}\text { Colistin } \\
\text { Sulphafurazole } \\
\text { Both }\end{array}$ & $\begin{array}{l}1 \\
+ \\
- \\
-\end{array}$ & $\begin{array}{l}2 \\
+ \\
- \\
-\end{array}$ & $\begin{array}{l}3 \\
+ \\
- \\
-\end{array}$ & $\begin{array}{l}4 \\
+ \\
- \\
-\end{array}$ & $\begin{array}{l}5 \\
+ \\
+ \\
-\end{array}$ & $\begin{array}{l}6 \\
+ \\
+ \\
-\end{array}$ & $\begin{array}{l}7 \\
+ \\
+ \\
-\end{array}$ & $\begin{array}{l}8 \\
+ \\
+ \\
+\end{array}$ & $\begin{array}{l}9 \\
+ \\
+ \\
+\end{array}$ \\
\hline 2 & $\begin{array}{l}\text { Colistin } \\
\text { Sulphafurazole } \\
\text { Both }\end{array}$ & $\begin{array}{l}+ \\
- \\
-\end{array}$ & $\begin{array}{l}+ \\
- \\
-\end{array}$ & $\begin{array}{l}+ \\
- \\
-\end{array}$ & $\begin{array}{l}+ \\
- \\
-\end{array}$ & $\begin{array}{l}+ \\
+ \\
+\end{array}$ & $\begin{array}{l}+ \\
+ \\
-\end{array}$ & $\begin{array}{l}+ \\
+ \\
-\end{array}$ & $\begin{array}{l}+ \\
+ \\
+\end{array}$ & $\begin{array}{l}+ \\
+ \\
+\end{array}$ \\
\hline 1 & $\begin{array}{l}\text { Polymyxin B } \\
\text { Sulphafurazole } \\
\text { Both }\end{array}$ & $\begin{array}{l}+ \\
- \\
-\end{array}$ & $\begin{array}{l}+ \\
- \\
-\end{array}$ & \pm & $\begin{array}{l}t \\
+ \\
-\end{array}$ & $\begin{array}{l}+ \\
+ \\
+\end{array}$ & $\begin{array}{l}+ \\
+ \\
+\end{array}$ & $\begin{array}{l}+ \\
+ \\
+\end{array}$ & $\begin{array}{l}+ \\
+ \\
+\end{array}$ & $\begin{array}{l}+ \\
+ \\
+\end{array}$ \\
\hline 2 & $\begin{array}{l}\text { Polymyxin B } \\
\text { Sulphafurazole } \\
\text { Both }\end{array}$ & $\begin{array}{l}+ \\
- \\
-\end{array}$ & $\begin{array}{l}+ \\
\pm \\
\pm\end{array}$ & $\begin{array}{l}\dot{1} \\
+ \\
-\end{array}$ & $\begin{array}{l}+ \\
+ \\
-\end{array}$ & $\begin{array}{l}+ \\
+ \\
+\end{array}$ & $\begin{array}{l}+ \\
+ \\
+\end{array}$ & $\begin{array}{l}+ \\
+ \\
+\end{array}$ & $\begin{array}{l}+ \\
+ \\
+\end{array}$ & + \\
\hline
\end{tabular}

Sulphafurazole alone inhibits both strains.

furazole over colistin or polymyxin B decreased the bactericidal effect in spite of a static concentration of the latter drugs (see also zone example in Fig. 3d).

Broth adjusted to $p \mathrm{H} 8 \cdot 4$, using $\mathrm{N} \mathrm{NaOH}$ and phenol red as indicator, and to $p \mathrm{H} 5 \cdot 2$, using $\mathrm{N} \mathrm{HCl}$ and bromocresol purple as indicator, was used as diluent in the next experiment using one isolate with both combinations of drugs. A weaker inoculum was used. Viable counts were not performed. The results are in Table $\mathrm{V}$.

It can be seen that the synergistic effect is maintained over the $p \mathrm{H}$ range $5 \cdot 2$ to $8 \cdot 4$. It may be noted here that sulphonamide drugs are recommended for use at $p \mathrm{H}$ values in excess of 7 because of their greater solubility at this $p \mathrm{H}$. It was noted in this experiment that a low $p \mathrm{H}$ value itself had an in-
TABLE III

BACTERIOSTATIC AND BACTERICIDAL EFFECT IN A RESISTANT STRAIN

Drug

Colistin

Sulphafurazole

Both

Polymyxin B

Sulphafurazole

Both

Dilutions $^{1}$

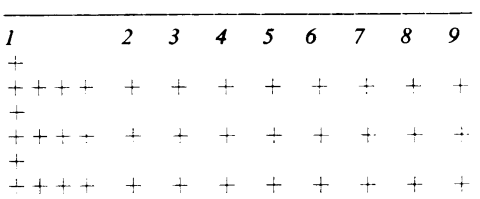

$+=$ acid production, i.e., growth

$+++t=$ confluent growth

${ }^{1}$ As in Table I.

Sulphafurazole alone has no action on this strain.

hibitory effect on growth, a fact also widely known and previously utilized in the treatment of urinary infections with ammonium chloride.

The apparently potentiating effect of the low $p \mathrm{H}$ has not been investigated further. It would be prudent to avoid undue acidity in treating a urinary infection with a sulphonamide drug.

Blood agar base (Oxoid) containing colistin methane sulphonate was used to test isolates of Proteus against the following sulphonamides:Sulphafurazole, sulphamethiazole, sulphadiazine, sulphadimidine, and sulphatriad. It was found that a concentration of $2.5 \mu \mathrm{g}$. colistin per ml. gave results comparable with sensitivity test agar (Oxoid) using a dilution technique of inoculation. If the concentration was raised to $25 \mu \mathrm{g}$. per $\mathrm{ml}$. no dilution of

TABLE II

BACTERICIDAL EFFECT IN SENSITIVE STRAINS

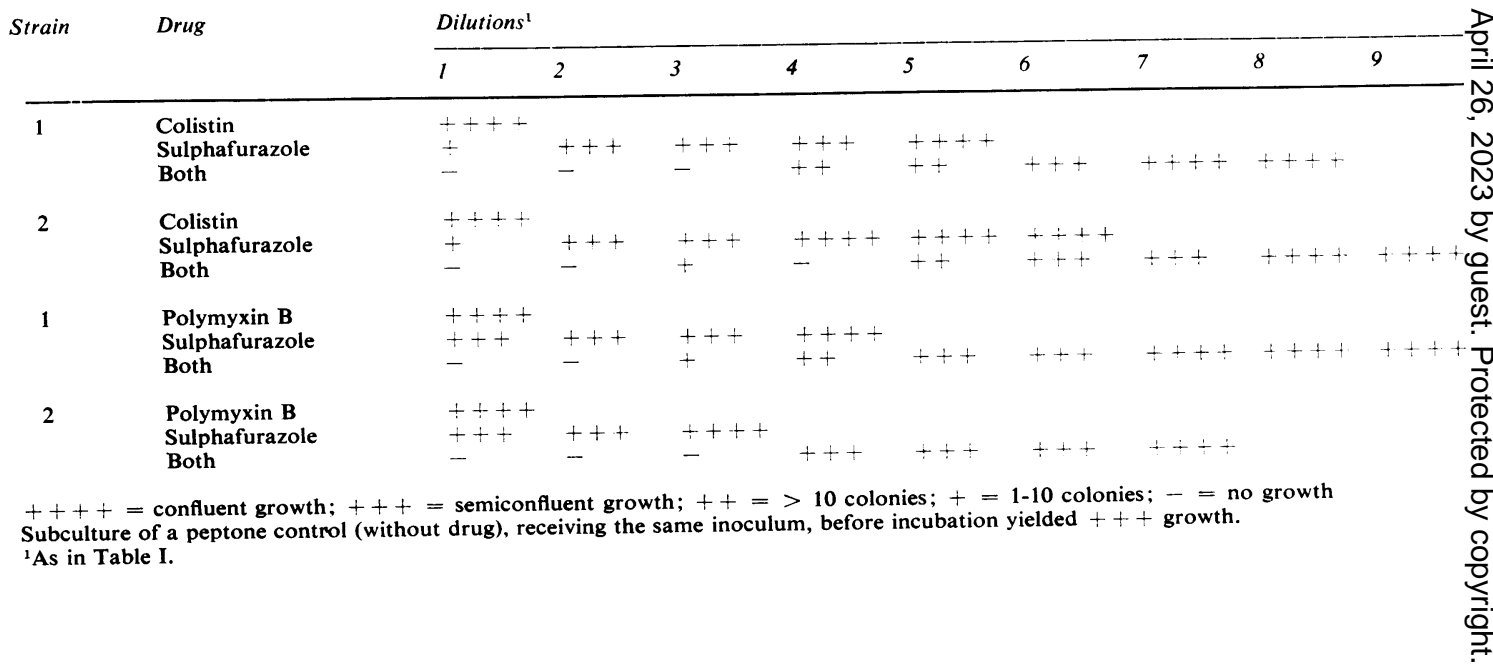


TABLE IV

EFFECT OF VARYING DRUG RATIOS

Drug

Concentration of Drug in Tube 1 (ug. per ml.)

Doubling Dilutions

\begin{tabular}{lllllllll}
\hline 1 & 2 & 3 & 4 & 5 & 6 & 7 & 8 & 9
\end{tabular}

\section{Strain I}

Sulphafurazole

Sulphafurazole

Colistin

Sulphafurazole

Colistin

Sulphafurazole

Colistin

$\left\{\begin{array}{l}100 \\ 100 \\ 400 \\ 100 \\ 100 \\ 400 \\ 100\end{array}\right.$

$\begin{array}{ll}+++ & +++ \\ - & - \\ - & - \\ - & -\end{array}$

+++
-
++

\begin{tabular}{|c|c|c|c|c|c|}
\hline $\begin{array}{l}+++ \\
++\end{array}$ & $\begin{array}{l}+t+ \\
t+t\end{array}$ & $\begin{array}{l}+++t \\
++\end{array}$ & $\begin{array}{l}++t \\
++t\end{array}$ & $\begin{array}{l}+++ \\
++t+\end{array}$ & $\begin{array}{l}++t+ \\
+t+t\end{array}$ \\
\hline++ & ++ & +++ & $++t$ & $+t+t$ & ++++ \\
\hline$+t$ & $+t+$ & $++t$ & $+t+$ & $+t+t$ & $+t+t$ \\
\hline
\end{tabular}

Strain 2

Sulphafurazole

Sulphafurazole

Polymyxin B

Sulphafurazole

Polymyxin B

Sulphafurazole

Polymyxin B

$\left\{\begin{array}{l}100 \\ 100 \\ 400 \\ 100 \\ 100 \\ 400 \\ 100\end{array}\right.$

$\begin{array}{llll}++ & ++ & ++ & +++ \\ - & - & - & - \\ - & - & - & - \\ - & - & - & -\end{array}$

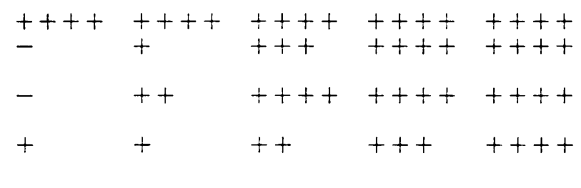

The inoculated controls gave ++ growth before incubation.

TABLE V

ACTION OF $p H$ ON SYNERGISTIC EFFECT

\begin{tabular}{|c|c|c|c|c|c|c|c|c|c|c|c|}
\hline \multirow{2}{*}{$\begin{array}{l}p \mathrm{H} \text { of } \\
\text { Medium }\end{array}$} & \multirow[t]{2}{*}{ Drug } & \multirow{2}{*}{$\begin{array}{l}\text { Concentration } \\
\text { of Drug in } \\
\text { Tube } 1 \\
\text { ( } \mu \text { g. per ml.) }\end{array}$} & \multicolumn{9}{|c|}{ Doubling Dilutions } \\
\hline & & & 1 & 2 & 3 & 4 & 5 & 6 & 7 & 8 & 9 \\
\hline $\begin{array}{l}8 \cdot 4 \\
8 \cdot 4\end{array}$ & $\begin{array}{l}\text { Sulphafurazole } \\
\text { Sulphafurazole } \\
\text { Colistin }\end{array}$ & $\begin{array}{l}100 \\
100 \\
400\end{array}$ & $\begin{array}{l}+ \\
-\end{array}$ & + & 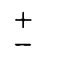 & $\begin{array}{l}+t+ \\
-\end{array}$ & $\begin{array}{l}++ \\
-\end{array}$ & $\frac{t+}{-}+$ & $\begin{array}{l}+++t \\
+\end{array}$ & $\begin{array}{l}++++ \\
++\end{array}$ & $\begin{array}{l}+++t \\
++\end{array}$ \\
\hline $5 \cdot 2$ & Sulphafurazole & 100 & - & - & - & - & - & - & + & ++ & ++ \\
\hline $5 \cdot 2$ & $\begin{array}{l}\text { Sulphafurazole } \\
\text { Colistin }\end{array}$ & $\begin{array}{l}100 \\
400\end{array}$ & - & - & - & - & - & - & - & - & - \\
\hline $\begin{array}{l}8 \cdot 4 \\
8 \cdot 4\end{array}$ & $\begin{array}{l}\text { Sulphafurazole } \\
\text { Sulphafurazole } \\
\text { Polymyxin B }\end{array}$ & $\begin{array}{l}100 \\
100 \\
400\end{array}$ & + & $\begin{array}{l}+ \\
-\end{array}$ & $\begin{array}{l}++ \\
-\end{array}$ & $\begin{array}{l}+++ \\
-\end{array}$ & $\begin{array}{l}+++ \\
-\end{array}$ & $\begin{array}{l}+++ \\
-\end{array}$ & $\begin{array}{l}+++t \\
+++t\end{array}$ & $\begin{array}{l}+++ \\
+++t\end{array}$ & $\begin{array}{l}++t+ \\
+++t\end{array}$ \\
\hline $\begin{array}{l}5 \cdot 2 \\
5 \cdot 2\end{array}$ & $\begin{array}{l}\text { Sulphafurazole } \\
\text { Sulphafurazole } \\
\text { Polymyxin B }\end{array}$ & $\begin{array}{l}100 \\
100 \\
400\end{array}$ & - & - & - & - & - & - & $\begin{array}{l}++ \\
-\end{array}$ & $\begin{array}{l}++ \\
-\end{array}$ & $\begin{array}{l}++t \\
++t\end{array}$ \\
\hline
\end{tabular}

Inoculated controls gave + growth and ++++ growth after incubation in both alkaline and acid media but growth by inspection was obviously less in the incubated broths at the lower $p H$. Repetition of sulphafurazole alone at both $p H$ levels serves as a control.

TABLE VI

SULPHONAMIDE SENSITIVITIES ON ANTIBIOTIC-IMPREGNATED AGAR

\begin{tabular}{|c|c|c|c|c|c|c|c|c|c|c|c|}
\hline \multirow{2}{*}{$\begin{array}{l}\text { No. of } \\
\text { Strains }\end{array}$} & \multicolumn{2}{|c|}{ Sulphafurazole } & \multicolumn{2}{|c|}{ Sulphamethiazole } & \multicolumn{2}{|c|}{ Sulphadimidine } & \multicolumn{2}{|c|}{ Sulphadiazine } & \multicolumn{2}{|c|}{ Sulphatriad } & \multirow[t]{2}{*}{ Peptome } \\
\hline & Colistin & Polymyxin ${ }^{1}$ & Colistin & Polymyxin & Colistin & Polymyxin & Colistin & Polymyxin & Colistin & Polymyxin & \\
\hline $\begin{array}{r}1 \\
4 \\
20\end{array}$ & $\begin{array}{l}- \\
\pm \\
+\end{array}$ & $\begin{array}{l}- \\
\pm \\
+\end{array}$ & $\begin{array}{l}- \\
\pm \\
+\end{array}$ & $\begin{array}{l}- \\
\pm \\
+\end{array}$ & $\begin{array}{l}- \\
\pm \\
+\end{array}$ & $\begin{array}{l}- \\
\pm \\
+\end{array}$ & $\begin{array}{l}- \\
\pm \\
+\end{array}$ & $\begin{array}{l}- \\
\pm \\
+\end{array}$ & $\begin{array}{l}- \\
\pm \\
+\end{array}$ & $\begin{array}{l}- \\
\pm \\
+\end{array}$ & $\begin{array}{l}\text { Acid } \\
\text { Acid (weak) } \\
\text { No acid }\end{array}$ \\
\hline
\end{tabular}

inoculum was required to produce clear-cut zones of inhibition with sulphonamides.

A blood agar base was prepared containing $25 \mu \mathrm{g}$. colistin methane sulphonate per $\mathrm{ml}$. and $25 \mu \mathrm{g}$. polymyxin B sulphate per $\mathrm{ml}$. and dispensed in roughly $10 \mathrm{ml}$. amounts in plastic Petri dishes. The plates were then seeded in duplicate with the 25 isolates of Proteus under test (24 showing synergism) from overnight broth cultures. Discs (Mast), 
to MacConkey agar to verify the presence of Proteus. The results are shown in Table VI.

No significant difference in the size of zones was noted in the series of plates containing colistin and those containing polymyxin B. Attempts to display the synergistic effect on plates from subcultures of colonies within the zones of inhibition failed. This is probably the result of mutation.

\section{DISCUSSION}

Many clinicians, especially those dealing frequently with urinary infections, feel that Proteus infections often respond to sulphonamide therapy in spite of pessimistic laboratory reports. These experiments confirm that one drawback of including sulphafurazole on standard Multodisk sets is that the bacteriostatic effect against Proteus is often underestimated, particularly with heavy infections and routine inoculation techniques.

The drugs which commonly inhibit Proteus species are chloramphenicol, streptomycin, kanamycin, ampicillin, and sulphonamides. It not infrequently happens that an isolate of Proteus is apparently sensitive to chloramphenicol and kanamycin only, and these simple experiments show that a large proportion of such strains are susceptible in vitro to a combination of a sulphonamide and colistin methane sulphonate or polymyxin B sulphate. Colistin methane sulphonate has been so far found free from serious toxic effects and from pain at the injection site (Edgar and Dickinson, 1962; McMillan, Price, McLaren, and Scott, 1962; Marsden and Hyde, 1962). Polymyxin B sulphate causes pain at the site of injection (Edgar and Dickinson, 1962).

Synergism between sulphonamides and both polymyxin B and colistin has been described before (Herman, 1959; 1961), and it is interesting that the synergism in this instance was first noted between sulphafurazole and the recently introduced colistin. This was due to the much higher concentration of colistin methane sulphonate in sensitivity discs as compared with polymyxin B sulphate (300 $\mu \mathrm{g}$.: $10 \mu \mathrm{g}$.) which made the synergistic effect easily noticed on a routine plate.

It would appear that colistin is chemically so closely related to the known polymyxins as to merit inclusion in the group (Stewart, 1962). It has been noted that when used to treat infections with Ps. pyocyanea Proteus strains were not uncommonly isolated during and after treatment (McMillan et al., 1962). Such cases seem to offer a clear indication for combined therapy.

The synergistic effect is easily observed by routine methods of inoculating plates. (This does not apply as described to polymyxin $\mathbf{B}$, the routine discs containing only $10 \mu \mathrm{g}$. of antibiotic.) The variation in zone size which was noted was probably due to a varying inoculum.

The ratio of drugs to one another, and the $p \mathrm{H}$ at which they act are not critical.

Mutant colonies were noted in four out of the 24 'sulphonamide-sensitive' strains, and it is unlikely that such strains would be eradicated by therapy.

It is interesting that the tube tests in such cases show a degree of resistance.

I am indebted to Mr. A. W. Miller, F.I.M.L.T., for much belp; to Miss Margaret Graham for her positioning of the Colomycin disc, which made the original observation possible, and subsequent help; and to Miss Lesley Robertson for preparing the media used. My thanks are also due to Mr. R. Callander (medical artist) and to Mr. G. Kerr (departmental photographer).

\section{REFERENCES}

Carroll, G., and Malette, W. F. (1961). J. Urol., 85, 86.

Cuthbert, M. F. (1962). Lancet, 1, 383.

Edgar, W. M., and Dickinson, K. M. (1962). Ibid., 2, 739.

Herman, L. G. (1959). Antibiot. Ann. (1958-59), pp. 836-839.

- - (1961). In Antimicrobial Agents and Chemotherapy. Proceedings of the First Interscience Conference on Antimicrobial Agents and Chemotherapy, 1961.pp. 943-952. American Society for Microbiology, Detroit.

McMillan, M., Price, T. M. L., McLaren, D. M., and Scott, G. W. (1962). Lancet, 2, 737.

Marsden, H. B., and Hyde, W. A. (1962). Ibid., 2, 740.

Stewart, G. T. (1962). Ibid., 1, 326.

Taylor, G., and Allison, H. (1962). Brit. med. J., 2, 161. 